\title{
Strategic Job Analysis and Competency Modeling in HRM: Lessons from Manufacturing Firms in Bangladesh
}

\author{
AKM Mominul Haque Talukder \\ School of Business, North South University, Dhaka 1229, Bangladesh \\ momin@northsouth.edu
}

\begin{abstract}
The research examines the determinants of job analysis and competency models affecting employee's motivation and competencies in a manufacturing firm. Data were obtained from a readymade garments based on structured questionnaire. Results show that competency has no relationship with rewards, motivation, and job description. Conversely, competency is positively related with performance appraisal, motivation, training, and selection process. The study also reports that rewards and job specifications are futile to leverage employee's competencies. It further suggests that harnessing these variables might contribute the firm with potential to enhance motivation and competency level to a greater extent.
\end{abstract}

Keywords: Performance appraisal, training, selection process, motivation, competency.

\section{Introduction}

Job analysis is the most useful tools for gathering information and developing content valid and legally defensible selection procedures for a wide variety of jobs (Harvey, 1991). A fundamental assumption of traditional job analysis is that the information about a job as it presently exists is useful for developing selection procedures because the job will be similar in the future (Schneider and Konz, 1989). Unfortunately, current trends in organizations (e.g. downsizing and reorganization) often result in the creation of new or re-designed jobs (Howard, 1995). In these situations, the assumption of job stability may often be untenable and traditional job analysis techniques may neither be possible nor be appropriate. As a result, there is a need for job analyst to develop new methods for identifying the key tasks and the knowledge, skills and abilities (KSAOs) that are required for jobs that are changing (Landy et al. 1995). Broadly defined, job analysis involves collecting data about observable job behaviors, and delineating the knowledge, skills, abilities, and other characteristics needed to perform the job (Cascio \& Aguinis, 2005). This broad definition is typically broken into two separate approaches to job analysis: worker-oriented job analysis and task oriented job analysis. Worker-oriented job analysis is often referred to as job specification and deals with the necessary KSAOs for successful completion of the job.

Competency modeling is typically defined as the identification, definition, and measurement of the KSAOs that are needed to perform the job successfully (Bartram, 2004). Competency modeling can be carried out using a few different approaches, but the most common are the individual job level and the organization level (Mansfield, 1996). The former deals with identifying the characteristics (i.e., KSAOs) that are necessary to be successful in a particular job (often referred to as a bottom-up competency model, and is quite similar to job analysis), whereas the latter takes into account organizational objectives, vision, and strategy and attempts to develop a set of competencies that are applied to the entire organization, a department within the organization, or a job family within the organization (Lawler, 2005).

The competencies in a model may be organized in a variety of formats. No one approach is inherently best. Rather, organizational needs will determine the optimal framework.A common approach is to identify several "core" or "key" competencies that are essential for all employees, and then identify several additional categories of competencies that apply only to specific subgroups. Some competency models are organized according to the type of competency, such as leadership, personal effectiveness, or technical capacity. Other models may employ a framework based on job level, with a basic set of competencies for a given job family and additional competencies added cumulatively for each higher job level within the job family (Marrelli and Tondora, 2005). Competency is an employee's ability to perform the skills required for a specific job (Spencer \& Spencer, 1993). Citing research that dates back half a century (McClelland, Baldwin, Bronfenbrenner, \& Strodtbeck, 1958), competency advocates have argued that assessments of employees' competencies provide an effective method for predicting job performance (McClelland, 1973). 
The research focuses on the impact of factors that lead to strategic job analysis and competency modeling in a local company in Bangladesh. Aspects like performance appraisal, reward, training, job description, selection process, motivation and competency are linked with the success of a company and interdependent on each other for initiating and sustaining a company's success. However, with increasing competition, shorter product life-cycles, rapid technological innovations, and the changing nature of organizational structures, its underlying assumptions are becoming increasingly questionable in today's dynamic work environment. Moreover, the methods used by traditional job analysis are simply not applicable to many new and emerging jobs and some authors feel it may even be an obstacle to organizational success. The objective of the study is to carry out a quantitative study of how the company is affected by job analysis and competency modeling. The antecedents of job analysis and competency models would moderate motivation while augmenting human capital of employees in the organization. As well as the study would contribute to the prevailing literature review and put forward new direction to manage human resource.

\section{Review of Literature}

Job analysis involves gathering data about desired job behaviors and identifying the knowledge, skills, abilities, and other characteristics needed to perform the job (Cascio \& Aguinis, 2005). Strategic job analysis involves proactively identifying the necessary task, behaviors, and KSAOs required for a job in the future (Schneider \& Konz, 1989). This method represents a change from descriptive job analysis to predictive job analysis. The need for strategic job analysis has become more evident due to the dynamic nature of modern-day organizations and as organizations try to hire, train, and appraise the performance of new positions (Sackett \& Laczo, 2003). Despite the growing need for strategic job analysis research on this topic has been limited with most of the available literature on the topic being prescriptive in nature and focusing largely on how to carry out a strategic job analysis.

The use of competencies to identify high-performing people, or outstanding employees, has gradually become widespread in human resource management (Lawler, 1994; Ulrich, 1997). Those characteristics that set these employees apart provide the basis for recruitment, selection, and development strategies that are effective and provide a high return on investment. In rapidly changing business environments, organizations are recognizing the value of a workforce that is not only highly skilled and technically adept, but more importantly, a workforce that can learn quickly, adapt to change, communicate effectively, and foster interpersonal relationships. These characteristics, or competencies, are critical to organizational survival, productivity, and continual improvement. Using competencies as the basis for staffing provides the flexibility needed to select and place individuals where they can best serve the organization. One of the strengths of competency models is that they are often linked to the business goals and strategies of the organization (Rodriguez et al. 2002). As Howard (1996) and Cascio (1996) have indicated, the changing nature of work requires evaluating worker competencies that are different from those evaluated in the past. Predictions are that work will become more difficult, more fluid, and more interconnected. As a result, the competencies needed by future workers will change. Intellect will be a necessary but not sufficient requirement. Employees will need to be smart, to be able to learn and grow, but at the same time be adaptable, responsible, and able to work with others.

Bitter and Gardner (1995) reported the tendency of supervisors to attribute the cause of poor performance to low motivation. Motivation represents an employee's desire and commitment to perform and is manifested in job related effort. It is the factor that keeps the human active and makes them feel good about their job. Competency is the combination of knowledge, skills and behavior used to improve performance; or is the state or quality of being adequately or well qualified, having the ability to perform a specific role. Motivation is a driving force behind a successful employee. If there is no motivation employee might lose enthusiasm. If manager's assessment is incorrect and poor performance is related to ability rather than motivation, the response to increased pressure will worsen the problem. If poor performers feel that management is insensitive to their problems-that they lack resources, adequate training, or realistic time schedules-they may respond counterproductively to any tactics aimed at increasing their efforts. Motivation is important not only to increase productivity but also to elevate competencies of employees in the organizations.

Performance appraisal is a process that identifies, evaluates and develops employee performance to meet employees and organizational goal. It typically involves measuring how well an individual employee is doing their job against a set of criteria. It also helps to judge who need promotion, training and so forth. 
Dowling et al. (1999) state that international performance management is a strategic HRM process that enables the MNCs to evaluate and continuously improve individual, subsidiary unit and corporate performance against clearly defined, pre-set objectives that are directly linked to international strategy. Performance appraisal is considered as one of several key elements of performance management.Cardy and Dobbins (1994) define performance appraisal as the process of identifying, observing, measuring and developing human resources in organizations. An effective performance appraisal system encourages individual performance by reinforcing organizational objectives. This is accomplished by establishing personal performance objectives that are congruent with overall organizational goals. In turn then, encouraging individual performance through performance appraisal promotes overall organizational performance (Katsanis, Laurin, \& Pitta, 1996). Performance appraisal is an important process for influencing both the extrinsic and intrinsic motivations of employees and their attitudes towards companies. Thus it can be hypothesized that,

H1: Performance appraisal will positively affect the motivation and competencies of employees in the organization.

Reward drives working capacity and motivates to work harder. A successful company formulates its reward by considering both organizational capability and employee expectations. This may include short term or long term planning consisting of variable and fixed pay plan that may include the fixed pay, fringe benefits, overtime payments, increments, bonuses, perquisites, reward policies etc. A successful company formulates its reward by considering both organizational capability and employee expectations. This may include short term or long term planning consisting of variable and fixed pay plan that may include the fixed pay, fringe benefits, overtime payments, increments, bonuses, perquisites, reward policies etc. Reward should be utilized as a strategic tool to manage corporate performance and to influence corporate values and beliefs (Kessler, 2003). Reward management is a key element in the strategic approach to HRM for a number of reasons such as employers aim to elicit effort and performance; the actual payment system may require adjustment to develop motivation; and it is often a significant part of the employer's financial strategy (Hendry, 1994). Therefore it is hypothesized that,

H2: A proper rewards package will positively affect the motivation and competencies of employees in the organization.

Selection process function helps an organization to effectively select the right people for the organization. However, it is very important for the recruitment process to be unbiased, free of discrimination and maintain equity. The criteria should promote task oriented and merit based selection of employees by following all the rules of the process so that the organizations' requirements are fulfilled. A good selection process reduces the cost of re-recruitment. So, it's a vital part in an organization. Successful organizations of the future will attract, engage, develop, and retain the best and brightest employees. Success will belong to those organizations who define return on investment not only in terms of profit and loss but also as the development and aggregation of human and intellectual capital (Rich, 2000). Therefore it is hypothesized that,

H3: Appropriate selection process will positively affect the motivation and competencies of employees in the organization.

Training is an effective and efficient way to develop skills, morale and leadership qualities within the employee. It also helps to build a wide range of activities that will enhance the quality of work life. Training has to be properly assessed so that the courses meet the objectives. Supervisor has to be well informed and capable for conducting the training. Training and evaluation is must. Because identifying the benefit coming from the training helps to identify the success of the training and also helps to modify it in case of necessary. The term training refers to the acquisition of knowledge, skills, and competencies as a result of the teaching of vocational or practical skills and knowledge that relate to specific useful competencies. It forms the core of apprenticeships and provides the backbone of content at institutes of technology. Even as organizations continue to look to training to contribute to long-term strategic goals, training professionals are redefining themselves as broad-based change agents and performance improvement consultants (Galagan, 2003). As a result, many organizations are more likely to include training solutions as part of a system wide change to gain a competitive edge. Therefore it is hypothesized that,

H4: Training is positively related with motivation and competencies of employees in the organization 
A job description outlines the responsibilities of a position as well as the employee's work environment. It includes a position title as well as information about the people who report to the employee or the people to whom the employee reports. Job descriptions are critical for a variety of legal and business-related purposes in companies of all sizes. Job descriptions help employees understand the tasks for which they are accountable so they can prioritize their work based on which duties are more critical than others. In addition, a manager can compare an employee's performance with the job description's standards and suggest specific tasks the employee can perform better. Managers can use job descriptions to determine the areas they should focus on when training employees. Employers decide how much to pay employees by determining the monetary worth of their professional abilities and responsibilities. Job descriptions allow employees to reflect on their own work and ensure they are meeting a company's standards prior to undergoing a performance review with a manager. Regular performance reviews typically occur annually and can influence raises and promotions. Job descriptions give managers the standards they should look for when hiring new employees. Employers typically include full job descriptions in job postings to attract qualified candidates. Companies use job descriptions to help plan which positions they can trim through a layoff or how to change the structure of a business, which affects employees' job duties. Therefore it is hypothesized that,

H5: Timely reshuffling job description is positively related to employee motivation and competencies in the organization.

Conceptual Model: Most research studies have an explicit or implicit theory, which describes, explains, predicts or controls the phenomenon under study. Theories are linked to conceptual models and frameworks; whereas a conceptual model is more abstract than a theory and a theory may be derived from a model, the framework is derived deductively from the theory (Burns \& Groves, 2001). A model is developed (Figure 1) which is derived from the review of the literature by integrating theory and research relating to different components of strategic job analysis and competency. It includes performance appraisal, rewards, training, job description, and selection process as independent variables and their relationship with motivation and competencies of the employee as dependent variables.

\section{Figure 1: Conceptual framework of research variables and their relationships}

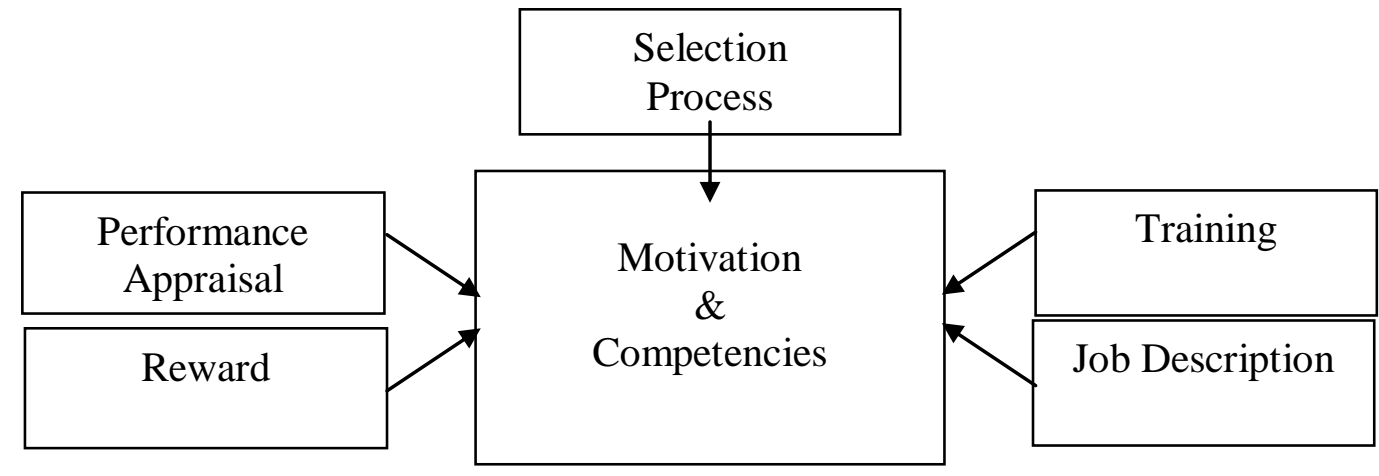

\section{Methodology}

A self-administered questionnaire survey of 150 first-line and middle managers was conducted in mid 2010 to assess their perceptions of job analysis and competency modeling. Valid surveys were received from 108 respondents, for an effective response rate of $72 \%$. After considering missing information in some questionnaires, 100 filled out formats were counted for analysis. The study adopts convenience sampling approach and chosen firm was readymade garments manufacturer of Newtex Group in Dhaka, Bangladesh. The questionnaire was divided into seven sections and designed to be scale rated. The items in each section were in the form of statements that were direct, simple and concise. Fixed alternative with Likert 5 scale (e.g., 1= highly disagree, 2=moderately disagree, 3=neutral, 4=moderately agree, and $5=$ highly agree) was used. The survey was administered by professional team members with physical presence in the organization. The questionnaire format comprised of variables such as performance appraisal, rewards, training, job description, selection process, motivation and competencies. Data gained is analyzed with SPSS for Windows 11.5. In order to test the hypothesis, the analyses of Pearson Correlation and linear regression were used. 
Factor Analyses After having data, reliability test was conducted which is a measure of consistency of the items within each variable. This helped analyzing the degree to which the items in each variable were dependable. This is vital as reliability is a prerequisite for validity which is a measure of the degree of relationship between the items assessed and actual results. By considering an alpha value of 0.8 and above $(\alpha>0.8)$, inconsistent items in the questionnaire were eliminated and the reliability test was rerun by factor analysis i.e. data reduction technique. Since the study relies exclusively on self-report measures as such relatively stringent rules-of-thumb already applied and retained only items with a strong loading of 0.5 or higher on the target construct (Nunnally and Bernstein, 2007).

\section{Results and Discussion}

Hypothesis 1 predicts that performance appraisal (PA) is positively related with motivation and competencies. As displays across Table 1 that PA is significantly related with motivation $\left(\mathrm{r}=.33^{* *}\right)$ and competencies $\left(\mathrm{r}=.35^{* *}\right)$. Thus hypothesis is accepted. Regression results in Table 2 also supports (Motivation, $\beta=.33$; Competencies, $\beta=.35$ ) that both motivation and competencies are positively related with PA.

Table1: Descriptive Statistics, correlations, and reliabilities

\begin{tabular}{llllllllll}
\hline Variables & Mean & SD & $\mathbf{1}$ & $\mathbf{2}$ & $\mathbf{3}$ & $\mathbf{4}$ & $\mathbf{5}$ & $\mathbf{6}$ & $\mathbf{7}$ \\
\hline 1. Performance Appraisal & 4.39 & .41 & $(.81)$ & & & & & & \\
2. Reward & 4.08 & .41 & $.27^{* *}$ & $(.81)$ & & & & & \\
3. Training & 3.47 & .52 & $.21^{*}$ & $.45^{* *}$ & $(.81)$ & & & & \\
4. Job Description & 4.41 & .52 & $.35^{* *}$ & -.04 & -.16 & $(.8)$ & & & \\
5. Selection Process & 4.33 & .44 & $.34^{* *}$ & $.21^{*}$ & .02 & $.54^{* *}$ & $(.8)$ & & \\
6. Motivation & 4.41 & .39 & $.33^{* *}$ & -.01 & -.12 & $.56^{* *}$ & $.28^{* *}$ & $(.81)$ \\
7. Competencies & 3.78 & .42 & $.35^{* *}$ & $.5^{* *}$ & $.56^{* *}$ & .03 & $.3^{* *}$ & .05 & $(.8)$ \\
\hline$N=100,{ }^{* *} p<.01,{ }^{*} p<.05$ & & & & & & & & &
\end{tabular}

Hypothesis 2 predicts that reward is positively related with motivation and competencies. The study finds that reward is positively related with competencies $\left(\mathrm{r}=.5^{* *}\right)$ while reward has no relationship with motivation. Hence, hypothesis 2 is partially accepted with regard to competencies but rejected with regard to motivation. Regression results in Table 2 also supports the hypothesis for competencies $(\beta=.5)$ but for motivation it indicates negative relationship $(\beta=-.01)$. Hypothesis 3 predicts that training is positively related with motivation and competencies. The study finds no relationship of training with motivation but it is positively related with competencies $\left(r=.56^{* *}\right)$. Thus hypothesis is partially accepted. Regression results also shows that training affects competencies positively $(\beta=.56)$ but it has not relationship with motivation $(\beta=-11)$.

Table 2. Regression results of the variables affecting motivation and competencies

\begin{tabular}{|c|c|c|c|c|c|c|c|c|}
\hline \multirow[t]{2}{*}{ Variables } & \multicolumn{4}{|c|}{ Motivation } & \multicolumn{4}{|c|}{ Competencies } \\
\hline & $\beta$ & $\mathrm{T}$ & $\mathrm{F}$ & $\mathrm{AR}^{2}$ & $\beta$ & $\mathrm{T}$ & $\mathrm{F}$ & $\mathrm{AR}^{2}$ \\
\hline Performance Appraisal & $.33^{*}$ & 3.5 & 12.3 & .1 & $.35^{*}$ & 3.7 & 13.8 & .12 \\
\hline Rewards & $-.01^{*}$ & -.13 & .02 & -.01 & $.5^{*}$ & 5.7 & 32.6 & .24 \\
\hline Training & $-.11^{*}$ & -1.1 & 1.13 & .001 & $.56^{*}$ & 6.6 & 44.2 & .3 \\
\hline Job Description & $.56^{*}$ & 6.6 & 44.3 & .3 & $.03^{*}$ & .26 & .07 & -.01 \\
\hline Selection Process & $.28^{*}$ & 2.9 & 8.6 & .07 & $.29 *$ & 2.9 & 8.9 & .1 \\
\hline
\end{tabular}

Hypothesis 4 predicts that job description is positively related with motivation and competencies. As exhibits in Table 1 that job description is positively related with motivation ( $\left.\mathrm{r}=.56^{* *}\right)$ but it has no relationship with competencies. As such hypothesis is partially accepted. Regression results in Table 2 represents that job description affects motivation $(\beta=.56)$ strongly and but competencies is weakly related $(\beta=.03)$ with job description. Hypothesis 5 predicts that selection process is positively related with motivation and competencies. As exhibits in Table 1 that it is positively related with motivation 
$\left(\mathrm{r}=.28^{* *}\right)$ and competencies $\left(\mathrm{r}=.3^{* *}\right)$. As such hypothesis is accepted. Regression results in Table 2 represent that selection process affects both motivation $(\beta=.28)$ and competencies $(\beta=.29)$.

The study finds positive relationship of performance appraisal with motivation and competencies of employees. As stated by Armstrong and Baron (2007) performance management aims to make the good better, share understanding about what is to be achieved and develop the capacity of people to achieve it, and provide the support and guidance people need to deliver high performance and achieve their full potential to the benefit of themselves and the organization. The study demonstrates that reward is positively related with competencies while it has no relationship with motivation. This can be justified what Lewis (2006) and Guthrie (2007) said that reward systems can influence a number of HR processes and practices which in turn impact organizational performance. Skills or competencies based reward is seen as more appropriate for those organizations that have flexible, relatively permanent workforce that is oriented towards learning. It is important that HR professionals see the reward system not solely as something in its own right, but also considers the links with organization strategy and other human resource practices. Simply selecting a scheme just because it is seen as the latest fad is likely to lead to failure. No management should regard the adoption of a reward system as the complete and final solution to problems of reward policy. Indeed, there is a view that every scheme which is implemented however satisfactorily contains the seeds of its own destruction (Watson, 1986). An individuals or groups bring their own interests to bear on the system, this means that subsequently it becomes very difficult to manage as interests become embedded, and the system serves certain groups rather than the organization as a whole. The study indicates no relationship of training with motivation but it is positively related with competencies. Zheng, Morrison \& O'Neill (2006) reported that training has positive effects on competency. If training is to be connected with individual and organizational performance, employees must be motivated and the continuous pursuit of development activities by individuals can be a key aspect in attaining training effectiveness in organizations (Noe, 1986). In fact, there is an increasing awareness in organizations that the investment in training could improve organizational performance in terms of increased sales and productivity, enhanced quality and market share, reduced turnover, absence and conflict, (Huselid, 1995). In contrast, training has been criticized as faddish, or too expensive (Kraiger, McLinden \& Casper, 2004), and there is an increasing skepticism about the practice and theoretical underpinning of linking training with firm performance (Wright \& Geroy, 2001).

In another study, Birdi, Allen and Warr (1997) proposed that motivation to learn is most relevant to how much an employee learns during training, but it has also been used to explain how much employees participate in training activities. This expanding notion of motivation to learn has helped with the theoretical maturation of the construct. Baldwin, et al. (1988) reported that employees' motivation to learn was linked to actual learning in a training program that was designed to improve skills for performance appraisal and feedback. Moreover, Noe and Wilk (1993) noted that an employee's motivation to learn is critical for training effectiveness. The study finds that job description is positively related with motivation but it has no relationship with competencies. Job descriptions are of value to both the employees and the employer. Job descriptions can be used to help employees learn their job duties and to remind them of the results they are expected to achieve. It can serve as a basis for minimizing the misunderstandings that occur between managers and their subordinates concerning job requirements. Management also establishes right to take corrective action when the duties covered by the job description are not performed as required (Bohlander and Snell, 2004). The study reports that appropriate selection process is positively related with motivation and competencies. Patterson et al (1997) found acquisition and deployment of employee skills through the use of sophisticated selection, induction, training and appraisals have a positive impact on company productivity and profitability. It is true that organizations succeed or fail on the basis of talents of employees, and then managers directly influence that success by the people they hire. Regardless of whether the company is large or small, hiring the best and the brightest employee lays a strong foundation for excellence (Bohlander and Snell, 2004). By identifying competencies through job analysis managers can then use selection methods such as interviews, references, psychological tests, and the like to measure applicant KSAOs against competencies required for the job.

\section{Conclusion and Recommendations}

The study found positive relationship of performance appraisal, job description, and selection process with motivation and competencies. But it did not find any relationship of reward and training with motivation. It is crucial to understand that the choice of reward systems depends on particular 
circumstances of the organization, the technology, the characteristic of the labor market and employee attitudes. Managers need to think carefully about the conditions under which a reward scheme will operate and the messages it will send to various audiences. A contingency approach, in which managers pick a scheme appropriate to their organizational needs, is more likely to be successful. In reality, there is no right or wrong approach, so what matters is choosing a position which supports the culture and systems, and which produces the behavior necessary to enhance organizational effectiveness. Employers hope expenditures in training will yield a favorable return on their investment with emphasis on learning and skill development. However, little is done to assess the impact of this training on the behavior and performance of employees. Studies suggest that many training and development activities are implemented on blind faith in the hope that they will produce results. Rarely do training programs assess needs, establish specific objectives, or evaluate impact beyond the reaction level. Only a small portion of training budgets is spent to determine the effect of training on job performance and those organizations that do evaluate results often find little impact. Different competitive factors such as changing environment, tighter budget, downsizing and pressure for greater employee accountability result in more emphasis on performance appraisal in relation to employee's motivation and competencies.

The study identifies avenues for future research. It assessed the relationship of performance appraisal, reward, training, job description, and selection process with employee's motivation and competencies. Further research may examine strategic integration of all these determinants to HRM areas. Moreover, other internal as well as external factors might moderate motivation and competencies of the employees which was beyond the capacity of the study. The study was confined to a single firm in manufacturing industry. In order to draw a general conclusion on the relationship between determinants and competencies the sample size could have been bigger. Another limitation of the study is not to take into account the opinions of non-management employees. Future research may consider not only using multiple stakeholders to increase data credibility but also to undertake more firms both in manufacturing and service industry to make a comprehensive generalization in this area of study.

\section{References}

Armstrong, M. \& Baron, A. (2007). Managing Performance: Perfromance management in ation. London, CIPD.

Baldwin, T. T. \& Ford, J. K. (1988). Transfer of training: A review and directions for future research. Personnel Psychology, 41(1), 63-105.

Bartram, D. (2004). Assessment in organizations. Applied Psychology: An International Review, 53, $237-$ 259.

Birdi, K., Allan, C. \& Warr, P. (1997). Correlates of perceived outcomes of four types of employee development activity. Journal of Applied Psychology, 82, 845-857.

Bitter, M. E. \& Gardner, W. L. (1995). A mid-range of the leader/member attribution process in professional service organizations: The role of the organizational environment and impression management. In M.J. Martinko (Ed.), Attribution theory: An organizational perspective. Delray Beach, FL: St. Lucie Press.

Bohlander, G. \& Snell, S. (2004). Human Resource Management. Thomson International.

Burns, N. \& Groves, S. (2001). The practice of nursing research, conduct, critique \& utilization (4th ed). Toronto, Ontario: W. B. Saunders Company.

Cardy, R. L. \& Dobbins, G. H. (1994). Performance Appraisal: Alterative Perspectives, $1^{\text {st }}$ ed., South-Western.

Cascio, W .F. (1996). The changing world of work: Competencies for the future. In Human Capital: An innovative whole-person approach to competency assessment. Washington, DC: U.S. Office of Personnel Management, Personnel Resources and Development Center.

Cascio, W. F. \& Aguinis, H. (2005). Applied psychology in human resource management (6th ed.). Upper Saddle River, NJ: Pearson Prentice Hall.

Dowling, P., Welch, D. \& Schuler, R. (1999). International dimensions of human resources. Cincinnati, OH: South Western College Publishing.

Galagan, P. (2003). The future of the professions formerly known as training. Training and Development, $57(12), 26-38$.

Guthrie, J. (2007). Remuneration pays effects and work, in P. Boxall, J. Purcell and P. Wright (eds) The Oxford Handbook of Human Resource Management. Oxford, Oxford University Press

Harvey, R. J. (1991). Job analysis. In M. D. Dunnette \& L. Hough (Eds.), Handbook of Industrial and Organizational Psychology (2nd ed.). Palo Alto, CA: Consulting Psychologists Press. 
Hendry, C. (1994). Human Resource management: A strategic approach to employment. London, Butterworth.

Howard, A. (1995) A framework for work change. In A. Howard (ed.), The Changing Nature of Work. San Francisco, CA, Jossey-Bass.

Howard, A. (1996). The changing nature of work: Implications for assessment centers. The 24th International Congress on the Assessment Center Method, Washington, DC.

Huselid, M. A. (1995). The impact of human resource management practices on turnover, productivity, and corporate financial performance. Academy of Management Journal, 38(3), 635-672.

Katsanis, L. P., Laurin, J. P. \& Pitta, D. A. (1996). How Should Product Managers be Evaluated in Emerging Product Management Systems? Journal of Product and Brand Management, 5(6), 3-20.

Kessler, I. (2003). Pay and performance, in B. Towers (ed.) The Handbook of Employment Relations Law and Practice. London, Kogan Page.

Kraiger, K., McLinden, D. \& Casper, W. J. (2004). Collaborative planning for training impact. Human Resource Management, 43(4), 337-351.

Landy, F. J., Shankster-Cawley, L. \& Moran, S. K. (1995). Advancing personal selection and placement methods. In A. Howard (ed.), The Changing Nature of Work. San Francisco, CA, Jossey-Bass.

Lawler, E. (1994). From job-based to competency based organizations. Journal of Organizational Behavior, 15(1), 3-16.

Lawler, E. (2005). Creating high-performance organizations. Asia Pacific Journal of Human Resource Management, 43(1), 10-17.

Lewis, P. (2006). Reward Management, in T. Redman and A. Wilkinson (eds) Contemporary Human Resource Management, $2^{\text {nd }}$ edition. London, Financial Times/Pearson.

Mansfield, R. S. (1996). Building Competency Models: Approaches for Human Resource Professionals, Human Resource Management, 35(1), 7-18.

Marrelli, A. F. \& Tondora, J. (2005). Strategies for Developing Competency Models. Administration and Policy in Mental Health, 32, 537-538.

McClelland, D. C., Baldwin, A. L., Bronfenbrenner, U., \& Strodtbeck, F. L. (1958). Talent and Society. Princeton, NJ: Van Nostrand.

McClelland, D. C. (1973). Testing for competence rather than for intelligence. American Psychologist, 28, 114.

Noe, R. A. (1986). Trainees' attributes and attitudes: Neglected influences of training effectiveness. Academy of Management Review, 11(4), 736-749.

Noe, R. A. \& Wilk, S. L. (1993). Investigation of the factors that influence employees' participation in development activities. Journal of Applied Psychology, 78(2), 291-302.

Nunnally, J. C. \& Bernstein, I. H. (2007). Psychometric Theory, 3rd eds., New York: McGraw-Hill.

Patterson, M., West, M., Lawthorn, R. \& Nickell, S. (1997). Impact of People management Practices on Business Performance, Issues in People Management No. 22. London: CIPD.

Rich, A. (2000). Employees as investors/owners: Maximizing human capital net worth. Case study/panel discussion presented at Managing and Measuring Human Capital: Best Practices for Hiring, Developing and Preserving a Committed and Engaged Workforce, San Francisco.

Rodriguez, D., Patel, R., Bright, A., Gregory, D. \& Gowing, M. K. (2002). Developing Competency Models to Promote Integrated Human Resource Practices, Human Resource Management, 41(3), 309324.

Sackett, P. R. \& Laczo, R. M. (2003). Job and work analysis. In W.C. Borman, D.R. Ilgen, and R.J. Klimoski (Eds.), Handbook of psychology: Industrial and Organizational Psychology (12, 21-37). Hoboken, NJ: Wiley.

Schneider, B. \& Konz, A. M. (1989). Strategic job analysis. Human Resources Management, 28(1), 51-63.

Spencer, L. M., Jr. \& Spencer, S. M. (1993). Competence at work: Models for superior $\quad$ performance. New York: John Wiley.

Ulrich, D. (1997). Human resource champions. Cambridge, MA: Harvard Business School Press.

Watson, T. (1986). Management, Organization, and Employment Strategy. London, Routledge \& Kegan Paul.

Wright, P. C. \& Geroy, G. D. (2001). Changing the mindset. International Journal of Human Resource Management, 12(4), 586-600.

Zheng, C., Morrison, M. \& O'Neill, G. (2006). An empirical study of high performance HRM practices in Chinese SMEs. International Journal of Human Resource Management, 17(10), 1772-1803. 